\title{
APPLICATION OF THE NUCLIDE-VECTOR METHODOLOGY TO DETERMINE THE ACTIVITY OF DIFFICULT-TO-MEASURE RADIONUCLIDES IN RADIOACTIVE WASTE STREAMS
}

\author{
Varlakov A. P. ${ }^{1}$, Sergeecheva Y. V. ${ }^{1}$, Ivliev M. V. ${ }^{1}$, Varlakova G. A. ${ }^{1}$, Gorbunov V.A. ${ }^{2}$, Karlin S. V. ${ }^{2}$ \\ ${ }^{1}$ JSC VNIINM, Moscow, Russia \\ ${ }^{2}$ Federal State Unitary Enterprise - United Ecological, Scientific and Research Center for Decontamination \\ of Radioactive Waste (RW) and Environmental Protection (FSUE «RADON»), Moscow, Russia
}

Article received on December 11, 2019

\begin{abstract}
Nuclide-vector method (scaling-factor method) is used to determine the radiation characteristics of radioactive waste based on the identified dependences between the contents of difficult-to measure radionuclides $\left.{ }^{239} \mathrm{Pu},{ }^{241} \mathrm{Am}\right)$ and key radionuclides $\left({ }^{60} \mathrm{Co},{ }^{137} \mathrm{CS},{ }^{152} \mathrm{Eu},{ }^{154} \mathrm{Eu}\right)$. This method allowed to reduce the number of sampling operations and advanced radiochemical analysis of radioactive waste during its categorization, personnel exposure, the total time and cost of operations performed during waste characterization. The paper describes the application of the nuclide-vector method enabling to identify the radiation characteristics of a large amount of radioactive waste with complex composition, containing difficult-to-measure radionuclides along with relevant demonstration of its effectiveness.
\end{abstract}

Keywords: radioactive waste, nuclide-vector method, difficult-to-measure radionuclide, confidence interval.

Regulatory requirements $[1-4]$ regarding radioactive waste (hereinafter referred to as RW) accounting and management state that RW composition and activity should be monitored at all waste management stages, i. e. during its collection, segregation, transportation, processing and storage.

If large amounts of waste are generated, prompt and reliable identification of RW specific and total activity given the limited time and resources being in place appears an urgent task to be addressed. To determine the activity of radionuclides contained in RW, both experimental and calculation methods are used. These methods are based on preliminary direct and/or indirect measurements of monitored parameters.

To identify specific and total activity of radionuclides contained in the waste, both destructive and non-destructive control methods are applied
[5-7]. Gamma spectrometry is considered as a most common non-destructive testing methods applied for RW certification purposes [7]. However, the activity of so called difficult-to-measure radionuclides (for example, ${ }^{3} \mathrm{~N},{ }^{14} \mathrm{C},{ }^{36} \mathrm{Cl},{ }^{63} \mathrm{Ni}$, ${ }^{90} \mathrm{Sr},{ }^{99} \mathrm{Tc},{ }^{129} \mathrm{I}$, ${ }^{234} \mathrm{U},{ }^{239},{ }^{241} \mathrm{Pu}$ ) (hereinafter, referred to as DTM [8]) cannot be determined using this method since their decay is accompanied by a gamma emission considered insufficient to record the intensity and/or energy of the gamma rays by non-destructive measurement methods.

Destructive methods provide for RW sampling, preparation of loads, which often includes radiochemical isolation of individual radionuclides, load evaluation using alpha, beta, gamma spectrometry, liquid scintillation spectrometry, etc. Destructive control methods are commonly used in case if DTM alpha and beta-emitters are present within waste 
composition. Nevertheless, the application of destructive methods makes it hard to ensure the sample representativeness due to potential heterogeneity of RW distribution within the waste package and/or insufficient number of samples characterizing the waste volume, as well as the high cost and duration of the analysis.

In case of large volumes of homogeneous RW streams containing difficult-to-measure radionuclides, joint application of destructive and non-destructive testing methods is believed to provide an optimal result.

Radionuclide Vector method (referred to as nuclide vector method or scaling-factor method in literature abroad) is a RW characterization method based on the identification of correlation dependencies between the activities of radionuclides in a given RW stream [5, 8-11]. This method assumes joint distribution and accumulation of DTM and easy-to-measure radionuclides in RW streams, similar mechanisms of DTM and easy-to-measure radionuclide formation, their physical and chemical properties. Easy-to-measure radionuclides are considered as reference ones ("key nuclides", $\mathrm{KN}$ ) when it comes to the identification of DTM radionuclides.

At nuclear power plants and large enterprises involving common production processes, RW streams are quite stable. Assuming this, IAEA recommends $[8,10]$ to select the KN based on similarities in the behavior and the process of the radionuclide group formation.

However, application of the radionuclide vector method is somewhat limited in case if the radiation characteristics of waste generated by different waste stream mixing and involving a large number of different radionuclides are to be identified. In such radioactive waste, the number of potential KNs with optimal half-lives and gamma radiation exposure is limited. Therefore, it is not possible to select a KN for all DTMs solely based on the similarities in waste behavior, generation and chemical properties. In this case, to characterize the RW, a $\mathrm{KN}$ can be identified based on the correlation and regression analysis of the dependences between the measured specific activities of easy-to-measure and difficult-to-measure radionuclides found in samples of a given RW stream.

The essence of the method can be summarized as follows: samples are collected, loads are prepared and the specific activities of radionuclides are measured. Based on the measured specific activities, statistically significant correlation dependencies between the DTM and KN activities are identified. Coefficients of a linear regression equation describing the relationships between DTM and KN specific activities within the measured object are determined. Radiation characteristics of the RW are further checked by non-destructive methods with DTM activity being calculated based on $\mathrm{KN}$ specific activity.

The paper focuses on radiation characteristics of large RW amounts packaged into containers and containing difficult-to-measure and easy-to-measure radionuclides being identified based on the radionuclide vector method, as well as the reliability of the result obtained.

Initially measured RW accounted for LRW originated from several sources and accumulated in large-capacity tanks (each $\sim 200 \mathrm{~m}^{3}$ ), then LRW were subject to in-tank cementation. Cement matrix degradation had been occurring over time, thus, the RW was retrieved from the tanks, packaged into waste containers and cemented again. In this case, an RW stream is considered as the whole of containers containing RW from a single tank.

Samples of RW placed into containers and associated with a specific waste stream were collected using the RW mass core drilling method to determine the specific activity and to assess the uniformity of activity distribution of the measured radionuclides. Samples were collected by the "envelope method" applied along container surface area and its depth.

The specific activities of radionuclides in the samples were measured by high resolution gamma spectrometry, alpha and beta radiometry, alpha and beta spectrometry and LC spectrometry, also involving radiochemical pre-treatment of the samples. Representative RW samples were measured to determine their radionuclide composition, as well as the specific activities of the main radionuclides: ${ }^{60} \mathrm{Co},{ }^{90} \mathrm{Sr}$, ${ }^{137} \mathrm{Cs},{ }^{152} \mathrm{Eu},{ }^{154} \mathrm{Eu},{ }^{234} \mathrm{U},{ }^{238} \mathrm{U},{ }^{238} \mathrm{Pu},{ }^{239} \mathrm{Pu},{ }^{241} \mathrm{Am}$.

Based on the measured specific activities, radionuclides responsible for RW assignment to a specific RW class in keeping with [5] were identified: DTM ${ }^{239} \mathrm{Pu}$ and ${ }^{241} \mathrm{Am}$. Potential $\mathrm{KN}$ were selected as well, namely, ${ }^{60} \mathrm{Co},{ }^{137} \mathrm{Cs},{ }^{152} \mathrm{Eu},{ }^{154} \mathrm{Eu}$.

The specific activities of readily detectable radionuclides $\left({ }^{60} \mathrm{Co},{ }^{137} \mathrm{Cs},{ }^{152} \mathrm{Eu},{ }^{154} \mathrm{Eu}\right)$ in packages (containers of KMZ-3.1 type) were measured using CANBERRA mobile semiconductor gamma spectrometer with Genie-2000 software and ISOCS gamma-quantum registration calculation system.

To evaluate the homogeneity of the measured radionuclide activity distribution in the radioactive waste, samples were analyzed along the depths of the containers.

$V$ variation coefficient [12] was selected as a criterion showing the uniformity of the activity distribution: it characterizes the fraction of the averaged deviations from the mean value. According to statistics, if the value of the variation coefficient does 
not exceed $33 \%$, the population can be considered homogeneous (1):

$$
V=\frac{\sigma}{\bar{x}} \cdot 100 \%
$$

where $\sigma$ is the standard deviation, $\bar{x}$ is the average specific activity of a radionuclide.

Calculations showed uniform distribution of radionuclides along the height and layers inside the containers.

To build correlation dependencies between the activities of readily detectable $\left({ }^{60} \mathrm{Co},{ }^{137} \mathrm{Cs},{ }^{152} \mathrm{Eu}\right.$, $\left.{ }^{154} \mathrm{Eu}\right)$ and difficult-to-measure $\left({ }^{239} \mathrm{Pu},{ }^{241} \mathrm{Am}\right)$ radionuclides, additional sampling was performed. Due to the uniform radionuclide distribution along the container height, the samples represented a core drilled from the surface to the bottom of the container.

Then the obtained experimental data on the specific activities of the samples and established functional relationships between the activities of hardto-measure and easy-to measure radionuclides in each tank were processed.

The calculations assumed that the content of radionuclides in the samples or packages with RW from the tanks corresponded to the lognormal distribution model [5-9], therefore, the correlation coefficients were determined for the relationship between the logarithms of the measured radionuclide specific activities.

Pearson correlation coefficient $r_{x y}$ was calculated for $\ln \left(A_{\mathrm{DTM}}\right)-\ln \left(\mathrm{A}_{\mathrm{KN}}\right)$ pairs of data sets [12].

To evaluate the strength of the correlation relationship, generally accepted criteria were used suggesting that $r_{x y}$ absolute values of less than 0.3 evidence a weak bounding, $0.3-0.7$ - average bounding, over 0.7 - strong bounding.

The pairs of easy- and hard-to-measure radionuclides with a correlation coefficient $r_{x y}$ between the specific activity logarithms of over 0.7 were identified. A pair with the maximum $r_{x y}$ was chosen as the optimal one. An easy-to-measure radionuclide from the optimal pair was considered as a $\mathrm{KN}$ for the hard-to-measure one.

Using the data logs on the specific activity logarithms for the DTM and KN pairs, relevant dependencies were plotted in $\ln \left(\mathrm{A}_{\mathrm{KN}}\right)-\ln \left(\mathrm{A}_{\mathrm{DTM}}\right)$ coordinates. For the obtained dependencies, plotted were the trend lines, linear approximation and linear regression equations were calculated. Figures 1 and 2 provide some examples of correlation dependences for radionuclide pairs from a single tank.

The approximation equations presented in Figures 1 and 2 correspond to the regression equations for pairs of DTM and $\mathrm{KN}$ radionuclides expressed as:

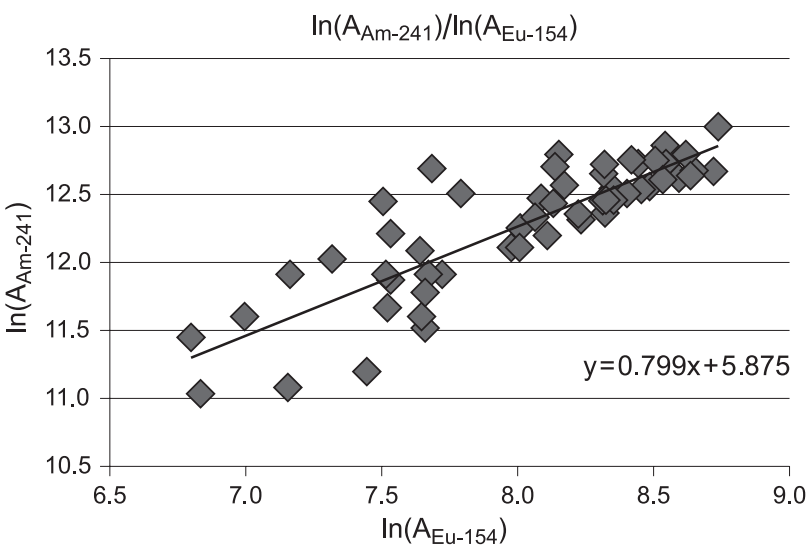

Figure 1. Correlation between $\ln \left(\mathrm{A}_{\mathrm{Am}-241}\right)$ and $\ln \left(\mathrm{A}_{\mathrm{Eu}-154}\right)$ from tank No 1

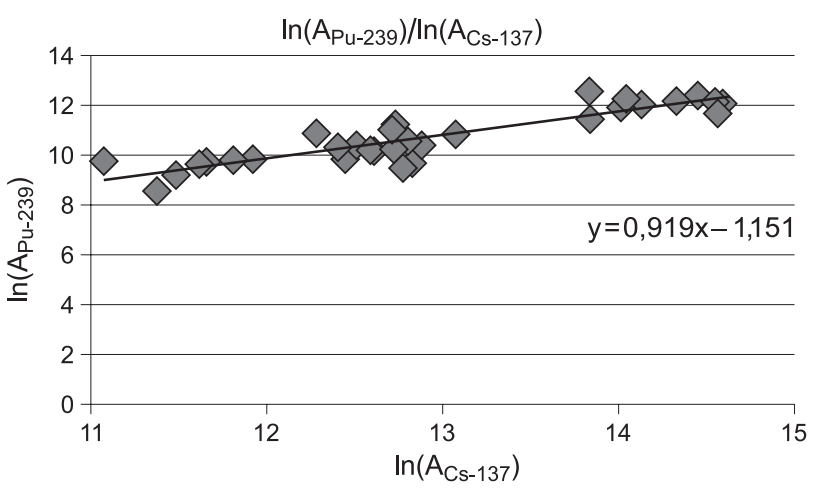

Figure 2. Correlation between $\ln \left(\mathrm{A}_{\mathrm{Pu}-239}\right)$ and $\ln \left(\mathrm{A}_{\mathrm{Cs}-137}\right)$ from tank No 1

$$
\ln \left(\mathrm{A}_{\mathrm{DTM}}\right)=\alpha \cdot \ln \left(\mathrm{A}_{\mathrm{KN}}\right)+\beta .
$$

For example, based on figure 1:

$$
\ln \left(A_{A m-241}\right)=0.799 \cdot \ln \left(A_{E u-154}\right)+5.875 .
$$

Regression equation coefficients were calculated using the Excel mathematical tools (CORREL, PIRSON, REGRESSION functions, etc. [13-15]).

Table 1 provides the regression equations for DTM ${ }^{239} \mathrm{Pu}$ and ${ }^{241} \mathrm{Am}$ from two tanks.

\section{Table 1. Pairs of hard-to-measure and reference} radionuclides and regression equations

\begin{tabular}{|c|c|c|c|}
\hline Tank & DTM & KN & Regression equations \\
\hline 1 & ${ }^{239} \mathrm{Pu}$ & ${ }^{137} \mathrm{Cs}$ & $\ln \left(\mathrm{A}_{\text {Pu-239 }}\right)=-2.292+1.029 \cdot \ln \left(\mathrm{A}_{\mathrm{Cs}-137}\right)$ \\
& ${ }^{241} \mathrm{Am}$ & ${ }^{154} \mathrm{Eu}$ & $\ln \left(\mathrm{A}_{\text {Am-241 }}\right)=5.857+0.799 \cdot \ln \left(\mathrm{A}_{\text {Eu-154 }}\right)$ \\
\hline 2 & ${ }^{239} \mathrm{Pu}$ & ${ }^{137} \mathrm{Cs}$ & $\ln \left(\mathrm{A}_{\text {Pu-239 }}\right)=0.010+0.847 \cdot \ln \left(\mathrm{A}_{\mathrm{Cs}-137}\right)$ \\
& ${ }^{241} \mathrm{Am}$ & ${ }^{137} \mathrm{Cs}$ & $\ln \left(\mathrm{A}_{\text {Pu-239 }}\right)=0.061+0.814 \cdot \ln \left(\mathrm{A}_{\mathrm{Cs}-137}\right)$ \\
\hline
\end{tabular}

Based on the obtained regression equations, ${ }^{239} \mathrm{Pu}$ and ${ }^{241} \mathrm{Am}$ specific activity in containers from which no samples were taken could be calculated using the gamma spectrometry method applied to 
measure the specific activity of reference radionuclides. DTM specific activities were calculated based on the following equation (4):

$$
\hat{\mathrm{A}}_{\mathrm{DTM}}=\mathrm{e}^{\beta} \cdot\left(\mathrm{A}_{\mathrm{KN}}\right)^{\alpha} \text {. }
$$

The confidence interval for the specific DTM activity calculated using scaling factors at $\mathrm{P}=0.95$ could be expressed as follows [14-16]:

$$
\hat{\mathrm{A}}_{\mathrm{DTM}}-\Delta_{\mathrm{A}_{\mathrm{DTM}}}^{-} \leq \mathrm{A}_{\mathrm{DTM}} \leq \hat{\mathrm{A}}_{\mathrm{DTM}}+\Delta_{\mathrm{A}_{\mathrm{DTM}}}^{+},
$$

where $\Delta_{\mathrm{A}_{\mathrm{DTM}}}^{-}$and $\Delta_{\mathrm{A}}^{+}$are the left and right confidence intervals, respectively, which can be calculated as:

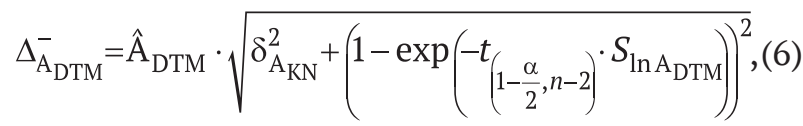

$\Delta_{\mathrm{A}_{\mathrm{DTM}}}^{+}=\hat{\mathrm{A}}_{\mathrm{DTM}} \cdot \sqrt{\delta_{\mathrm{A}_{\mathrm{KN}}}^{2}+\left(\exp \left(t_{\left(1-\frac{\alpha}{2}, n-2\right)} \cdot S_{\text {In } \mathrm{A}} \mathrm{DTM}\right)-1\right)^{2}},(7)$

where $\delta_{\mathrm{A}_{\mathrm{KN}}}$ is the relative measurement error for the reference radionuclide;

$S_{\ln \mathrm{A}_{\mathrm{DTM}}}$ is the standard deviation of the hard-tomeasure radionuclide activity logarithm.

The DTM specific activity calculated through the use of scaling factors can be presented as follows:

$$
\left\{\mathrm{A}_{\mathrm{DTM}}-\Delta_{\mathrm{A}_{\mathrm{DTM}}}^{-}, \mathrm{A}_{\mathrm{DTM}}+\Delta_{\mathrm{A}_{\mathrm{DTM}}^{+}}^{+}\right\}, \mathrm{Bq} / \mathrm{kg} \text {. }
$$

To check the applicability of the radionuclide vector method, the specific activities of hard-to-measure radionuclides calculated via the radionuclide vector method and measured by LC spectrometry method involving radiochemical pre-treatment were compared. Table 2 shows the obtained result of such comparison between the calculated and measured DTM specific activities.

Specific activity measurement error $\delta_{\mathrm{A}_{\mathrm{KN}}}$ in case of a non-destructive testing method implemented in accordance with common measurement technique amounted to $50 \%$. Substitution of this value into equations (6) and (7) showed that specific activity calculation error for a hard-to-measure radionuclide almost entirely depends on $\mathrm{KN}$ specific activity measurement error.

Table 2 shows that calculated and measured specific DTM activities differ by no more than $35 \%$. These data indicate good convergence of the results suggesting that the radionuclide vector method can be used to identify the radiation characteristics of large volumes of typical RW containing ${ }^{239} \mathrm{Pu}$ and ${ }^{241} \mathrm{Am}$.

\section{Conclusions}

The paper demonstrated the possibility of radionuclide vector method application in determining the radiation characteristics of RW streams characterized with complex composition and containing difficult-to-measure radionuclides:

- for a specified RW stream, correlation dependencies between specific activities of radionuclide pairs were identified, regression equation coefficients were calculated and KNs were selected (Table 1);

- specific DTM activities were identified based on $\mathrm{KN}$ measurements involving the use of a mobile gamma-ray spectrometer: prompt RW control was implemented to check KMZ-3.1 type containers with a total capacity of $600 \mathrm{~m}^{3}$;

- measured and calculated specific DTM activities

\begin{tabular}{|c|c|c|c|c|c|c|}
\hline Tank & DTM & KN & Measured $A_{\mathrm{KM}}, \mathrm{Bq} / \mathrm{kg}$ & Measured $A_{\text {DTM }}, B q / k g$ & Calculated $\hat{\mathrm{A}}_{\mathrm{DTM}}, \mathrm{Bq} / \mathrm{kg}$ & $\left(\hat{\mathrm{A}}_{\mathrm{DTM}}-\mathrm{A}_{\mathrm{DTM}}\right) / \hat{\mathrm{A}}_{\mathrm{DTM}}, \%$ \\
\hline \multirow{11}{*}{1} & \multirow{5}{*}{${ }^{239} \mathrm{Pu}$} & \multirow{5}{*}{${ }^{137} \mathrm{Cs}$} & $3.07 E+06$ & $4.24 \mathrm{E}+05$ & $4.75 E+05$ & 10.7 \\
\hline & & & $3.23 E+06$ & $6.53 E+05$ & $5.01 E+05$ & -30.3 \\
\hline & & & $3.35 E+06$ & $5.74 \mathrm{E}+05$ & $5.20 E+05$ & -10.4 \\
\hline & & & $2.88 E+06$ & $3.42 E+05$ & $4.45 E+05$ & 23.2 \\
\hline & & & $2.67 E+06$ & $2.78 \mathrm{E}+05$ & $4.12 E+05$ & 32.5 \\
\hline & \multirow{6}{*}{${ }^{241} \mathrm{Am}$} & \multirow{6}{*}{${ }^{154} \mathrm{Eu}$} & $3.67 E+03$ & $3.22 \mathrm{E}+05$ & $2.52 E+05$ & -27.8 \\
\hline & & & $4.10 E+03$ & $2.30 E+05$ & $2.75 E+05$ & 16.4 \\
\hline & & & $5.00 E+03$ & $2.84 \mathrm{E}+05$ & $3.22 E+05$ & 11.8 \\
\hline & & & $1.92 E+03$ & $2.66 E+05$ & $2.50 E+05$ & -6.4 \\
\hline & & & $3.91 E+03$ & $3.02 E+05$ & $2.65 E+05$ & -13.9 \\
\hline & & & $3.54 E+03$ & $1.20 E+05$ & $1.45 E+05$ & 17.2 \\
\hline \multirow{2}{*}{2} & ${ }^{239} \mathrm{Pu}$ & ${ }^{137} \mathrm{Cs}$ & $2.80 E+06$ & $3.10 E+05$ & $2.93 E+05$ & -5.8 \\
\hline & ${ }^{241} \mathrm{Am}$ & ${ }^{137} \mathrm{Cs}$ & $2.80 E+06$ & $2.27 E+05$ & $1.87 E+05$ & -21.4 \\
\hline
\end{tabular}
were compared showing that for the studied RW

Table 2. Comparison of measured and calculated DTM specific activities 
streams, the calculated and measured specific DTM activities differ by no more than $35 \%$ demonstrating the applicability of this method.

A technique was developed allowing to apply the radionuclide vector method to determin the specific DTM activity in typical waste streams being part of large RW batches with a complex composition. Based on the data obtained, guidance on the application of the radionuclide vector method in the identification of radiation characteristics for other RW streams was developed.

\section{References}

1. SP 2.6.1.2612-10. Osnovnye sanitarnye pravila obespecheniya radiacionnoj bezopasnosti (OSPORB-99/2010) [Basic sanitary rules for radiation safety].

2. Postanovleniye Pravitelstva Rossiyskoy Federatsii ot 19 oktyabrya 2012 g. N 1069 «O kriteriyakh otneseniya tverdykh, zhidkikh i gazoobraznykh othodov $\mathrm{k}$ radioaktivnym otkhodam, kriteriyakh otneseniya radioaktivnykh otkhodov $\mathrm{k}$ osobym radioaktivnym otkhodam i k udalyayemym radioaktivnym otkhodam i kriteriyakh klassifikatsii udalyayemykh radioaktivnykh otkhodov» [Decree of the Government of the Russian Federation of 19 October 2012 No.1069 "On the criteria of designation of solid, liquid and gaseous waste as radioactive waste, criteria of radioactive waste designation as non-retrievable radioactive waste and retrievable radioactive waste and criteria of classification of retrievable radioactive waste"].

3. NP-093-14. Federal'nye normy i pravila v oblasti ispol'zovaniya atomnoy energii "Kriterii priemlemosti radioaktivnyh othodov dlya zahoroneniya" [Federal codes and standards in the field of use of atomic energy "Criteria for acceptance of radioactive waste for disposal”].

4. NP-067-16. Federal'nye normy i pravila v oblasti ispol'zovaniya atomnoy energii "Osnovnye pravila ucheta i kontrolya radioaktivnyh veshchestv i radioaktivnyh othodov v organizacii" [Federal codes and standards in the field of use of atomic energy "Basic rules for accounting and control of radioactive substances and radioactive waste in an organization"].

5. RB-154-19. Rukovodstvo po bezopasnosti pri ispol'zovanii atomnoj energii. "Rekomendacii po primeneniyu metoda radionuklidnyh sootnoshenij dlya opredeleniya soderzhaniya slozhnodetektiruemyh radionuklidov $\mathrm{v}$ radioaktivnyh othodah predpriyatij yadernogo toplivnogo cikla" [Safety Guide for the Use of Atomic Energy. "Recommendations on the application of the radionuclide ratio method for determining the content of complex detectable radionuclides in the radioactive waste of nuclear fuel cycle enterprises"].

6. Zherebtsov A. A., Varlakov A. P., Germanov A. V., Sharov D. A., Eltsin V.F., Churakov A. K., Skakun G. E. Podhody $\mathrm{k}$ harakterizacii RAO, obrazuyushchihsya pri realizacii proekta «PRORYV» [Approaches to the characterization of RW generated during implementation of the project "PRORYV"]. Radioaktivnye othody - Radioactive Waste, 2018, no. 2 (3), pp. 88-94.

7. Verbitskij V. V. Harakterizaciya i pasportizaciya RAO [RW characterization and certification]. Bezopasnost' okruzhayushchej sredy - Environmental safety, 2010, no. 3, pp. 116-120.

8. IAEA Nuclear Energy Series NW-T-1.18. Determination and use of scaling factors for waste characterization in NPP. IAEA, Vienna, Austria, 2009.

9. ISO 21238-2007. Scaling factor method to determine the radioactivity of low- and intermediate-level radioactive waste packages generated at nuclear power plants.

10. IAEA-TECDOC-1537. Strategy and methodology for radioactive waste characterization. 2007.

11. Zherebcov A. A., Varlakov A. P., Germanov A. V., Mel'nikov M. V., Korotkov A. S., El'cin V. F., Churakov A. K. Metod ocenki soderzhaniya al'fa- i betaizluchayushchih radionuklidov $\mathrm{v}$ RAO radiohimicheskih proizvodstv po matrice prisutstvuyushchih gamma-izluchayushchih radionuklidov [Method for Assessment of Alpha- and Beta- Emitting Radionuclide Content in Radiochemical Production RAW by the Matrix of Present Gamma-Emitting Radionuclides]. Yadernaya i radiacionnaya bezopasnost' $-\mathrm{Nu}$ clear and radiation safety, 2017, no. 3(85), pp. 17-25. 12. Polyakova V. V., Shabrova N. V. Osnovy teorii statistiki [Basics of statistics theory]. Ekaterinburg, Ural. Feder. Univ. Publ., 2015. 148 p.

13. Ishkhanyan M. V., Karpenko N. V. Econometrica. Chast' 1. Parnaya regressiya [Econometrics. Chapter 1. Pair regression]. Moscow, MGUPS (MIIT) Publ., 2016. $117 \mathrm{p}$.

14. Korrelyacionnyj analiz. Ispol'zovanie MS Excel dlya rascheta koefficienta korrelyacii [Correlation analysis. Using MS Excel to calculate the correlation coefficient]. Kazan, Kaz. Gos. Med. Univ. Publ., 2011.

15. Kharchenko M. A. Korrelyacionnyj analiz [Correlation analysis]. Voronezh, VGU Publ., 2008. 31 p. 


\section{Information about the authors}

Varlakov Andrey Petrovich, Doctor of Sciences, Director of Department, JCS "VNIINM" (5a, Rogova St., 123098, Moscow, Russia), e-mail: APVarlakov@bochvar.ru.

Sergeecheva Yana Vladimirovna, Leading process engineer, JCS "VNIINM" (5a, Rogova St., 123098, Moscow, Russia), e-mail: yanasergeecheva@yandex.ru.

Ivliev Michail Vladimirovich, PhD, Head of department, JCS “VNIINM” (5a, Rogova St., 123098, Moscow, Russia), e-mail: MiVIvliev@bochvar.ru.

Varlakova Galina Andreevna, PhD, Main specialist, JCS “VNIINM" (5a, Rogova St., 123098, Moscow, Russia), e-mail: varlakova@inbox.ru.

Gorbunov Valery Alekseevich, Head of the central laboratory, FSUE "RADON” (2/14, 7 Rostovsky Lane, 119121, Moscow, Russia), e-mail:VaAlGorbunov@radon.ru.

Karlin Sergey Viktorovich, Head of technical preparation department, FSUE "RADON” (2/14, 7 Rostovsky Lane, 119121, Moscow, Russia), e-mail: SVKarlin@radon.ru.

\section{Bibliographic description}

Varlakov A. P., Sergeecheva Y. V., Ivliev M. V., Varlakova G. A., Gorbunov V. A., Karlin S. V. Application of the Nuclide-vector Methodology to Determine the Activity of Difficult-to-measure Radionuclides in Radioactive Waste Streams. Radioactive Waste, 2020, no.1(10), pp. 85-91. (In Russian). DOI: 10.25283/2587-9707-2020-1-85-91. 